\title{
Dariusz Słapek
}

Maria Curie-Skłodowska University in Lublin, Poland

ORCID: 0000-0002-9477-9697

d.slapek@poczta.umcs.lublin.pl

\section{Solidarism vs Marxism: "Legal Views of Slaves and Roman Proletarians" by Borys Łapicki Revisited}

\author{
Solidaryzm vs marksizm, czyli o "Poglądach prawnych niewolników \\ i proletariuszy rzymskich" Borysa Łapickiego raz jeszcze
}

\begin{abstract}
In the history of Polish Romanist studies in the period of the Polish People's Republic, Borys Lapicki attracts considerable attention due to his controversial monograph Legal Views of Slaves and Roman Proletarians from 1955. It seems that the work is not quite rightly treated as a breach in the career of the Romanist from Lodz. Reasons for this uniqueness are usually sought in a complicated biography of the author which is treated as a kind of a "sign of the times". Meanwhile, reviews of the work published right after it had been issued unequivocally showed that the dogmatic Marxism was in a way assessed as an adaptation by Lapicki, trying to reconcile it with the ideas of solidarism he had long accepted and belief in ethical values of the Roman law. Loyalty to these ideas made this amalgam of barely reconcilable concepts (class struggle in the light of harmony based on freedom and brotherhood) impossible to be accepted. It seems that this eclectic formula was never imposed by anyone on Łapicki - it was not a manifestation of the author's conformism or opportunism. Despite very severe criticism, he did not abandon it even in the times when historical materialism left the dogmatic phase of its development. This article is a case study - a contribution to the studies on a broader problem of identity and attitude of Polish Romanists in the period of Stalinism.
\end{abstract}

Keywords: Borys Łapicki; Roman slavery; Marxism; solidarism; the Roman law; Polish Romanist studies in the period of the Polish People's Republic

CORRESPONDENCE ADDRESS: Dariusz Słapek, PhD, dr. habil., Associate Professor, Maria Curie-Skłodowska University (Lublin), Faculty of Humanities, Plac Marii Curie-Skłodowskiej 5, 20-031 Lublin, Poland. 
It is not difficult to notice that a relatively small circle of Polish Romanists cultivates their own traditions with a special care and seeks a certain identity with a considerable veneration, taking care for the memory of their tutors, reputable authority figures, mentors, and all protagonists. This respect is revealed in numerous - not only occasional and jubilee - publications. It can be assumed that the scale of this interesting phenomenon allows to order the current of "identity" inquiries into some groups or subject series of academic studies. It is easy to see those amongst them which integrate with the power of extraordinary biographies or inspire a cool and distant assessment of the life achievements of many scholars, but one can also find those which concentrate attention on an almost prophetic significance of individual publications for the development of Romanist studies (it seems that one can already mention a group of young scholars specialising in the studies on the history of national Romanist). ${ }^{1}$

It seems that Borys Łapicki (1889-1974) was a figure who - as can be assumed - triggers interest of Romanists in nearly all of the above-mentioned contexts. Undoubtedly, a considerable number of publications written about him is a result of joint or individually uncovered plots: extraordinary biography/life, original research plans which were assertive to the state of research hypotheses, intellectual part/method which led to making usually controversial and - in this category always original conclusions. It would be in vain to ignore a rare alliance of these conclusions/visions with university didactics and, in the end, his attitude towards life. ${ }^{2}$ It is worth emphasising that evaluation in the scope of each of these analysis

${ }^{1}$ It seems highly symptomatic to emphasise the role of these publications, quite regularly present in the résumé of the achievements of the Polish studies on the Roman law. The greatest credit for this is due to Professor Maria Zabłocka (see, e.g., Romanistyka polska w pierwszym dziesięcioleciu XXI wieku, Warszawa 2013, pp. 152-162; Gorsze lata polskiej romanistyki, „Zeszyty Prawnicze UKSW” 2017, vol. 17(4), pp. 173-175; Badania romanistów polskich w latach 2011-2013, „Zeszyty Prawnicze UKSW" 2015, vol. 15(2), pp. 236-238). Cf. Ad laudem magistri nostri. Mistrzowie dzieła polskiej romanistyki, ed. E. Gajda, Torun 2018.

2 This footnote does not diversify publications on B. Łapicki according to their content. Usually they do not take a pure form in this respect. It is best to refer to them as academic biographies which - being eclectic in nature - combine together elements of biography, characteristics of achievements and broadly understood assessment of Łapicki. See J. Kodrębski, Borys Łapicki (1889-1974), „Czasopismo Prawno-Historyczne” 1974, vol. 26(2), pp. 287-288; idem, Borys Lapicki (1889-1974), [in:] Profesorowi Janowi Kodrębskiemu in memoriam, ed. A. Pikulska-Robaszkiewicz, Łódź 2000, pp. 93-115; idem, Dzieje Katedry Prawa Rzymskiego, „Acta Universitatis Lodziensis. Folia Iuridica” 1997, no. 64, pp. 41-42; idem, Borys Lapicki (1889-1974), „Zeszyty Naukowe Uniwersytetu Łódzkiego. Nauki Humanistyczno-Społeczne" 1976, no. 26, pp. 269-282; idem, Borys Eapicki, „ŁTN. Sprawozdania z Czynności i Posiedzeń 1924-1977” 1979, pp. 100-102; Borys Łapicki, „ŁTN. Sprawozdania z Czynności i Posiedzeń 1948” 1949, no. 1, p. 8; Prof. dr Borys Łapicki, „Prawo i Życie" 1974, no. 8, p. 2; M. Zabłocka, Borys Lapicki (1889-1974), [in:] Profesorowie Wydziału Prawa i Administracji Uniwersytetu Warszawskiego 1808-2008, ed. G. Bałtruszajtys, Warszawa 2008, pp. 162-163; T.A.J. Banyś, Ł.J. Korporowicz, Borys Łapicki, [in:] 70 lat Wydziału Prawa 
areas can lead to different conclusions; therefore, it is sometimes difficult to value and approve of their mechanically constructed sum. Only a prudent résumé on the "cases of Borys Łapicki" engenders (as a kind of a case study) a reason for a more extensive reflection on the attitudes of the Polish Romanist studies towards communism as an idea and practice of the functioning of a totalitarian state.

One of the methods which was rather frequently - and somewhat wrongly practised in recognising a role and significance of the achievements of individual researchers in the discipline is exclusively the analysis of their specific publications. Usually, the recognition of only one of them (while having a more extensive choice) as a classic and iconic work becomes for many reasons (e.g. diversification and dynamics of interests, turning points in the scholarly activities that are visibly different from their provenance in which this choice/evaluation is made) a rather risky procedure. ${ }^{3}$ The author of this article, being aware of these threats, decided

i Administracji Uniwersytetu Łódzkiego, eds. A. Liszewska, A. Pikulska-Radomska, Łódź 2015, pp. 129-135; J. Ożarowska-Sobieraj, M. Bromboszcz, Ideologia warstwy oświeconej - inteligencji rzymskiej okresu pryncypatu w pogladach Borysa Lapickiego, [in:] Egalitaryzm i elitaryzm. Tradycja i przyszłość Europy, eds. E. Kozerska, P. Sadowski, A. Szymański, Opole 2012, pp. 73-80; M. Jońca, Działalność Borysa Eapickiego w latach okupacji hitlerowskiej, [in:] Ad laudem magistri nostri..., pp. 59-74; M. Bromboszcz, Romanista w czasach stalinizmu - Borys Łapicki o powstaniach oraz walce niewolników z panami, [in:] Wojna i pokój. Wybrane zagadnienia prawno-historyczne, eds. E. Kozerska, P. Sadowski, A. Szymański, Opole 2013, pp. 75-87; J. Kita, S. Pytlas, Profesorowie Uniwersytetu Łódzkiego w latach 1945-1994. Pro memoria, Łódź 1995, pp. 132-134; W. Litewski, s.v. Lapicki Borys, [in:] idem, Stownik encyklopedyczny prawa rzymskiego, Kraków 2008, p. 308; B. Czech-Jezierska, Polscy romaniści w czasie II wojny światowej, „Studia z Dziejów Państwa i Prawa” 2018, vol. 21, pp. 388-389; eadem, Wolność i godność w starożytnym Rzymie - dobra osobiste czy spoteczne? Kilka uwag na tle pogladów Borysa Lapickiego, [in:] Naruszenie dobra osobistego $i$ zadośćuczynienie, Olsztyn (in print). From the perspective of the nature of Łapicki's achievements, it seems that the paper by B. Czech-Jezierska entitled Problem wtaściwej interpretacji źródet prawa rzymskiego w ujęciu ,romanistyki marksistowskiej”, given at the conference "Civis Romanus sum II. Problem interpretacji tekstu źródłowego", is also important.

3 This danger does not derive only from the fact that the assessment (presented in the literature in footnote 2) is made very much post factum because this kind of perspective probably brings out universal and ageless values of someone's achievements easier. However, it should not be forgotten that monographic works in particular also live a different life, the nature of which is decided by the reviews that come from that period. Current studies on the works published several years ago stems from slightly different needs; it is rather a kind of re-evaluation. However, the need for it also has to result from something - not only due to the reason of "obliterating memory and marginalisation" (see J. Ożarowska-Sobieraj, M. Bromboszcz, op. cit., p. 73; T.A.J. Banyś, Ł.J. Korporowicz, op. cit., p. 133), because "he was left into the oblivion of the academic circles" - and not be essentially reduced to the recollection of content of the discussed book (M. Bromboszcz, op. cit., p. 81 ff.). Otherwise, it will become a kind of a scholarly vintage, if one can use a style in culture and art in relation to a completely different sphere. However, the look into the past cannot be unreflective and marginalise the opinions from the historical period. In the assessment of the Legal Views, an important role is therefore played by the reviews published right after Łapicki's book was published. See B. Geremek, T. Łoposzko, rec. Borys Łapicki, Poglądy prawne niewolników i proletariuszy rzymskich. Studium 
however to apply a method - still not thoroughly verified - based on making one of the works a point of reference in the assessment of Łapicki's entire output (this is a path from detail to generalization).

In Łapicki's case, experts on his achievements distinguish at least two works even though it seems their choice falls more often on An Individual and the State in Ancient Rome. ${ }^{4}$ The reason behind it seems to be very important if only for the matter of re-evaluators (this term distinguishes between reviewers from the epoch and authors of assessments judged from the perspective of the history of Polish Romanist studies) extract from the above-mentioned and evaluated works what in their opinion is the most important and characteristic, and at the same time potentially vigorous, inspiring, and attractive for "implementation" by the contemporaries. In this context, these choices cannot, therefore, raise doubts. However, these occur when one looks at the present interest in Łapicki's life and scholarly activities (see numerous publications in footnote 2) with an eye of - let's just say - a statistician. A slightly changed hierarchy of the achievements of the Lodz Romanist emerges from that perspective. For it turns out that probably the most often mentioned (or rather remembered) work by the Romanist from Lodz are Legal Views of Slaves and Roman Proletarians. ${ }^{5}$ The context in which this takes place happens to be different, as different are the forms within which the memory on the Legal Views occurs from the history of the Polish Romanist studies, through biographies devoted to them, to detailed studies dealing almost exclusively with Łapicki. However, it seems that regardless of the types of interest in the Legal Views, all these remarks are linked

historyczne na tle bazy gospodarczej i antagonizmów klasowych, Łódzkie Towarzystwo Naukowe, Łódź 1955, s. 241, „Przegląd Historyczny” 1956, vol. 47(2), pp. 393-400; M. Staszków, W sprawie „Pogladów prawnych niewolników i proletariuszy rzymskich” (uwagi na tle pracy prof. Borysa Łapickiego), „Czasopismo Prawno-Historyczne” 1956, vol. 8(2), pp. 321-335; J. Češka, Łapicki, Borys. Poglady prawne niewolników i proletariuszy rzymskich, „Sborník prací Filozofické fakulty brněnské univerzity. E-Řada archeologicko-klasická" 1956, vol. 5(E1), pp. 193-196. In "Revue d'Histoire du droit français et étranger" (1957, vol. 34, p. 639), in the Chronicle in the section "Droits étrangers", information note was published, which cannot however be treated as a review. Another echo of the Legal Views is mentioned by J. Kodrębski (Borys Lapicki (1889-1974), [in:] Profesorowi Janowi Kodrębskiemu..., p. 110). This is, in fact, not an extensive discussion but rather a short information on the publication of the book in "Rivista internazionale di diritto romano e antico" (1957, vol. 8, p. 444), by Czech Assyriologist, Josef Klima.

${ }^{4}$ B. Łapicki, Jednostka i państwo $w$ Rzymie starożytnym. Rozważania historyczne na tle przeobrażeń prawa i państwa i prawa $w$ dobie obecnej, Warszawa 1939. Of great significance here is also the opinion of J. Kodrębski (Borys Lapicki (1889-1974), [in:] Profesorowi Janowi Kodrębskiemu..., p. 101), who regarded this monograph as the best in Łapicki's career. This suggestion was followed by T. Banach (Prawo rzymskie i etyka w pogladach Borysa Lapickiego, „Studia Iuridica Lublinensia” 2007, vol. 10, p. 97). Selection by J. Ożarowska-Sobieraj and M. Bromboszcz (op. cit., pp. 73-80), was appurtenant to Etyczna kultura starożytnego Rzymu a wczesne chrześcijaństwo (Wrocław-Lódź 1958).

${ }^{5}$ B. Łapicki, Poglady prawne niewolników i proletariuszy rzymskich. Studium historyczne na tle bazy gospodarczej i antagonizmów klasowych, Łódź 1955. 
by one elementary feature. This feature is an unchanging merging of constitutive and presented in the subtitle of the work: Historical Study against the Background of Economic Foundation and Class Antagonisms - methodological and ideological presuppositions of this monograph with the author's biography. The biographical motif is certainly taking on a variety of meanings in this juxtaposition and at times it seems to be closer to a classic biography (a sequence of events and episodes) while sometimes it becomes a sketch of a generation active in the times of Stalinism, just so that at other times it turns out to be closer to defining Łapicki's attitude towards life. The essence of this communication lies mainly in an attempt to solve a kind of a mystery (or an unrevealed truth) so to speak. For no one has so far given an unambiguous and convincing answer to the question on how it happened that the intellectual who had been brought up in the spirit of the Russian liberalism, ${ }^{6}$ the left-leaning professor of the pre-war Free Polish University, tolerant and sensitive lecturer of law at the University of Lodz, he suddenly moved down to a position of an orthodox supporter of historical materialism who - in a role of the author of the Legal Views - created a separate chapter in the history of the Polish Romanist studies which was always treated with considerable restraint. ${ }^{7}$

It seems that this problem cannot be reduced exclusively to tracing down different branches and shades of a biographical motif. Following this lead undoubtedly engenders a result of interpreting an actually fragile factual material. ${ }^{8}$ Even though one cannot thoroughly marginalise the "biographical background" of methodological (and ideological?) metamorphosis of Łapicki, it is worth noting huge difficulties in a correct understanding of the juxtaposed evidence on liberalism of the author of the Legal Views or the arguments in favour of his total "merging with the system". Here the Free Polish University dominated by the spirit of freedom clashes even with Łapicki's participation in the official delegation to the third Pan-Slavic

${ }^{6}$ It is a shame that J. Kodrębski did not get closer into Lapicki's attitude towards the very complex and diverse tendencies in the Russian liberalism. Did it concern the so-called "intellectual liberalism"? See more broadly in M.M. Przeciszewska, Dyskusje o rosyjskiej polityce liberalnej. Środowisko Partii Konstytucyjno-Demokratycznej, 1905-1914, Warszawa 2013 (doctoral dissertation written under the supervision of T. Kizwalter).

${ }^{7}$ A certain euphemism attached to this sentence is not able to conceal the willingness to address a key question: Did he believe? Cf. footnote 12 .

${ }^{8}$ Łapicki did not leave a diary behind. A biography handwritten by Łapicki is in the Archives of University of Lodz ( AUŁ, Personal documents of B. Łapicki no. 3836). It was used by J. Kodrębski (Borys Łapicki (1889-1974), [in:] Profesorowi Janowi Kodrębskiemu..., p. 100), but its usefulness in discovering "the ideological creation of the author" seems to be limited. Also the memoirs of his son, Andrzej (see . Bielas, J. Szczerba, Nie zabiliby panowie królika. Cz. 1. Rozmowa z Andrzejem Eapickim, „Gazeta Wyborcza”, 5.03.1999, http://niniwa22.cba.p1/lapicki_wywiad_1.htm [access: 10.12.2020]) are either overly laconic or have a rather illustrative dimension. 
Congress in the USA in $1946^{9}$, the liberal contents of the Theory of Law from 1947 and the lectures - unrestrained with the spirit of the age - based on its script, which somehow argue with inviting Łapicki to international congresses on the Roman law towards the end of the 1940s and the highest state distinctions granted to him a few years later. ${ }^{10}$ Personally, I do not intend to draw any significant conclusions from this "collisional" (consisting of a complex and unclear, or even mutually exclusive) material, and I would give my eye teeth to anyone who is able to form unequivocal views on Łapicki vs Marxism on the basis of the following opinion by Jan Kodrębski:

In the first years after the war, Łapicki was quite socially active and probably - if had decided to become fully subordinated to the then authorities - he could have had, as a classic type of a non-

9 The left-wing, liberal circles of Wszechnica (the pre-war Wszechnica of Warsaw as well as the post-war "emanation of Lodz") was given a lot of attention. They were mentioned by nearly every author of the works mentioned in footnote 2 . There are many various opinions on the topic of the "political aura" of University of Lodz. A. Zysiak (Punkty za pochodzenie. Powojenna modernizacja $i$ uniwersytet $w$ robotniczym mieście, Kraków 2016, pp. 54-58) points out that at its origins is was referred to as a "red university". Very little is written, however, on the political context of Lapicki's American escapade who, together with General K. Świerczewski represented Poland at the congress of association, the Sovietization and Communisation of which - started after 1944 - reached its apogee two years later, as one might assume. On the course of events, participants (delegation from the USSR consisted only of the Red Army generals) and anti-American dimension of the Congress, see Report on the Amercian Slav Congress and Associated Organizations, June 26, 1949, Washington 1950, pp. 22-26. Cf. S. Fertacz, Przyczynek do powstania i działalności Kongresu Słowian Amerykańskich w latach drugiej wojny światowej, „Kwartalnik Historyczny” 1993, no. 2, pp. 77-89. Reasons for including the Romanist from Lodz as part of the delegation are unknown. I did not find any evidence that Łapicki was in any way associated with the activities of the Komitet Słowiański w Polsce (The Slavic Committee in Poland). See M. Gruszczyk, Przyczynek do powstania i działalności Komitetu Stowiańskiego w Polsce w pierwszych latach po zakończeniu II wojny światowej, [in:] Władza a spoteczeństwo, eds. A. Bryłka, T. Kałuski, M. Korbaś, Katowice 2016, pp. 26-36.

${ }^{10}$ Liberalism of Teoria prawa wedtug wyktadów na Ut, by Lapicki, published in 1947 and similar in their political overtones - lectures by this author are strongly emphasized by J. Kodrębski (Wydziat Prawa i Administracji UŁ w l. 1945-1995. Szkic do historii, „Acta Universitatis Lodziensis. Folia Iuridica" 1997, no. 64, p. 12, 19; Borys Eapicki (1889-1974), [in:] Profesorowi Janowi Kodrębskiemu..., p. 104, 116). However, this refers only to the period until 1949. M. Jońca (op. cit., pp. 59, 69-71) mentions Łapicki's involvement in the works of the then Ministry of Justice. He also lists Łapicki's articles which contested political reality of the Second Republic of Poland. However, it should be remembered that the criticism of the London government in 1946-1947 did not indicate yet the ideological path leading exclusively to the inclusion of the communists. National distinctions from 1954-1955 are described by J. Kita and S. Pytlas (op. cit., p. 132), although it is impossible to draw any rational conclusions on this basis. Finally, to what extent is it possible to trust the anecdote (see R. Tokarczyk, Antologia anegdoty akademickiej, Warszawa 2006, p. 286), according to which Borys Łapicki asked a question during the exam about the class struggle in ancient Rome? Having heard a student's answer, full of quotations from the Marxism's classics, the professor commented on the words of the examined person with a certain satisfaction: "Excellent, excellent - only that there was no class struggle in ancient Rome". 
-partisan professor with a progressive past, a great career. Attempts to drag him towards this path had been made [...]. If the professor managed to avoid them, it happened as a result of his - as I think genuine aversion to representative distinctions and formal political ties, as well as a clear revulsion against totalitarian regimes which he had revealed in his publications already before the war. Like many people who were in the same situation, Łapicki maintained a far-reaching restraint in his political stance in communist Poland, but his experiences from Russia in 1911-1923 were undoubtedly affecting his attitude towards the communist authorities in Poland. The communist revolution from which he had escaped as a young scholar from Russia, caught up with him when he was already a mature scholar in Poland. ${ }^{11}$

Therefore, Kodrębski does not make conclusions or decision even if he is referred to as Lapicki's student and, undoubtedly, the source of the most precious information on his mentor and his scholarly achievements. ${ }^{12}$ May this restraint offer (another) conclusion that the biographic path turns out to be an uncertain lead, full not so much of traps but of temptations to take shortcuts, to make simplifications, to walk on shoals or overly swampy paths... ${ }^{13}$

However, it is worth to follow Kodrębski's route for one important reason. It seems that he was the only one who make a fully original - later often used and copied by other authors - holistic assessment of Łapicki's scholarly progress and output. Due to this, he pointed out rudimentary views of the Romanist from Lodz on the role and nature of the Roman law. They can even be referred to as a prevailing methodology which - apart from its nuances - always relates to strategy and begins with an answer to a question of such nature: How does a scholar understand the subject of exploration? In this recapitulation of Łapicki's academic achievements, there are certainly (as constant phenomena):

- unvarying display of the phenomenon of the ethics of law in which lies a human ethical ideal and a universal moral code, ${ }^{14}$

11 J. Kodrębski, Borys Łapicki (1889-1974), [in:] Profesorowi Janowi Kodrębskiemu ..., pp. 9798. Interestingly, this citation is an introduction to the article - in Kodrębski's mind it was an extremely important introduction - created to be even a kind of an alibi/justification to practically all of Łapicki's accomplishments.

12 J. Kodrębski (Dzieje Katedry..., p. 42) declared to be Łapicki's student, stating that: "In 1982 the chair of the Department was taken by a student of Borys Łapicki and a long-time associate of Cezary Kunderewicz, an assistant professor, Jan Kodrębski". Cursus honorum proves, however, that the mutual process of getting to know each other lasted only for a few years, from the period of Kodrębski's employment at University of Lodz to Łapicki's retirement (1958-1960/1). Cf. Pikulska-Radomska, Sylwetki łódzkich uczonych. Prof. Jan Kodrębski, Łódź 2008; I. Jakubowski, A. Pikulska-Radomska, Z. Rau, Jan Kodrębski (1936-1997), [in:] 70 lat Wydziału Prawa i Administracji..., p. 93.

${ }_{13}$ There is, in fact, still a significant instability in seemingly the most reliable evaluations. M. Jońca (op. cit., p. 60) cited an opinion by Professor Anna Pikulska-Radomska: "Wydaje się, że on naprawdę uwierzył..." ("It seems that he really believed...").

${ }^{14}$ Ethics as an iconic (although not original) feature in Łapicki's career was discussed by J. Kodrębski (Borys Łapicki (1889-1974), [in:] Profesorowi Janowi Kodrębskiemu ..., p. 104 [“thus, law is 
- interests and pursuit of studies of sociological and historical rather than dogmatic nature, with the obvious and constant - for that reason - opposition to a narrow legal formalism. ${ }^{15}$

If these achievements were to be extended also to didactics, then it is extremely important to distinguish between a strict alliance between scholarly views and academic content of lectures of Professor Łapicki who treated the ethical values of the Roman law as a kind of cannon and rudiment in educating lawyers. ${ }^{16}$

formalised ethics for Łapicki”], 99, 106, 107, 112). See also idem, Dzieje Katedry ..., p. 41: “[...] first and foremost, he was interested in the qualities of the Roman law, which according to him expressed the most valuable content of the moral culture of antiquity". This matter is approached slightly different by T. Banach (op. cit., p. 113), according to whom "the analysis of the relationship between law and ethics, that had been done by Borys Łapicki, is in fact ground-breaking in nature - thus, constituting a merit in itself" (see also ibidem, pp. 100-104, 108). As L. Górnicki (Prawo Trzeciej Rzeszy w nauce i publicystyce prawniczej Polski międzywojennej (1933-1939), Bielsko-Biała 1993, p. 234) wrote: "[...] according to us, his views had characteristics of natural-law depiction, a version equating law with ethics". In turn, M. Zabłocka (Borys Lapicki..., p. 162) wrote: “[...] he noticed ethical values in the Roman law and in these values - and not in legal technology - he noticed its greatest virtue". See also M. Bromboszcz, op. cit., p. 75; J. Ożarowska-Sobieraj, M. Bromboszcz, op. cit., pp. 74-75.

15 J. Kodrębski (Borys Lapicki (1889-1974), [in:] Profesorowi Janowi Kodrębskiemu ..., p. 111) presents Łapicki as "A scholar to whom the formal and dogmatic method was always strange, and who tried to capture in his studies the social reality rather than normative condition". Earlier he wrote: "Lapicki was firmly opposed to the legal positivism, and the major course of his works is dedicated to a key problem of the relationship between law and state - following the sociological school popular at the beginning of the $20^{\text {th }}$ century which was an understandable reaction to positivism" (ibidem, p. 99). Similarly: T. Banach, Prawo rzymskie i etyka..., pp. 98, 113-114; M. Staszków, op. cit., p. 321. Cf. unequivocal opinions on this matter by Łapicki (Poglady prawne..., pp. 8-9), and a remark he made in the biography he wrote: "My research and academic interests headed towards the Roman ideology and its relationship with Roman law. Therefore, [...] to avoid causations, I focused on key problems, in which Roman ideology found its vivid and fundamental expression" (quoted after J. Kodrębski, Borys Lapicki (1889-1974), [in:] Profesorowi Janowi Kodrębskiemu ..., p. 100). Inevitably, he accepted sociological and historical method. B. Wierzbowski (Treść władzy ojcowskiej w rzymskim prawie poklasycznym - władza nad osobami dzieci, Torun 1977, p. 10), stated that already in Władza ojcowska w starożytnym Rzymie. Okres królewski i republikański (Warszawa 1935), Lapicki was more interested in the social reality than the normative regulation. In turn, W. Litewski (op. cit., p. 308) treats him more as a historian of ideology than of Roman law. J. Kodrębski (Borys Lapicki (1889-1974), [in:] Profesorowi Janowi Kodrębskiemu..., p. 104) and M. Staszków (op. cit., p. 322) recommend reading Łapicki's work to the historians specialising in ancient Rome. On the other hand, R. Taubenschlag (,,Prawo rzymskie”, Borys Łapicki, Warszawa 1948 [rec.], „Czasopismo Prawno-Historyczne” 1949, vol. 2, p. 483) reproached Łapicki mainly for disregarding the dogmatic side of the Roman law.

${ }^{16}$ It can be inarguably state that Łapicki’s theories which were questioned in scholarship were never discredited in his university didactics. Let this matter be illustrated by only a few - but quite spectacular - comments, which should inspire the historians of Polish Romanist studies to undertake this topic as a separate research objective. J. Kodrębski (Wydział Prawa ..., p. 18) wrote: "The memory of Professor Łapicki survived amongst his students to this day because of his outstanding personality as well as significance he had ascribed to the ethical values of law. The moral ideal ex- 
This general statement can already imply risky conclusions. Firstly, it can be assumed that the presented "continuity perspective" necessitates to doubt in the validity of making some form of a major periodisation of Łapicki's academic achievements. ${ }^{17}$ In my opinion, one should rather talk about Lapicki's constant and consistent cultivation of a certain vision of the Roman law. It was not always unconditionally coherent and finished in its internal logic, but even in this form it turned out to be, and still remains, iconic to Łapicki. ${ }^{18}$

pressed - according to Lapicki - in Roman law had indicated to the students the moral dimension of the occupation they had chosen". The same author added: "Excellent lecturer who loved his discipline and deeply believed in its moral values [...], a role model of an academic teacher. His attitude made students fulfill their image of a university professor" (idem, Dzieje Katedry..., p. 41). See also A. Dzikowski, Nauczanie prawa rzymskiego na studiach prawniczych w Polsce w latach 1918-1989. Konflikt ideologiczny o znaczeniu praktycznym, „Kortowski Przegląd Prawniczy” 2017, no. 4, p. 20; J. Kodrębski, Borys Łapicki (1889-1974), [in:] Profesorowi Janowi Kodrębskiemu..., p. 98, 114; T.A.J. Banyś, Ł.J. Korporowicz, op. cit., p. 134; M. Jońca, op. cit., pp. 64-66; B. Czech-Jezierska, A. Dębiński, Prawo rzymskie w Polsce w latach 1939-1945, „Zeszyty Prawnicze” 2017, vol. 17(3), p. 34. The article by Łapicki, entitled O humanistycznym wychowaniu prawnika („Państwo i Prawo" 1948, no. 5-6, pp. 90-97), should undoubtedly enter the canon of books for law students. If R. Taubenschlag (op. cit., p. 483) took into the account Łapicki's intentions which accompanied the latter in the writing of the first post-war synthesis of Roman law (more broadly on Prawo rzymskie from 1948, see J. Kodrębski, Borys Łapicki (1889-1974), [in:] Profesorowi Janowi Kodrębskiemu ..., p. 107, 114; B. Czech-Jezierska, Prawo rzymskie w edukacji prawniczej w pierwszych latach Polski Ludowej (1944-1949), „Annales UMCS sectio G (Ius)” 2014, vol. 61(2), p. 41), the first sentences in the review of the Romanist from Warsaw would probably be devoid of a huge dose of irony...: "The book with the above-mentioned title intends to give young students a textbook on Roman law. Unlike other textbooks, which according to the author's claim (p. 12) present only the technique of Roman law, his textbook is illuminated by 'socio-ethical value' of individual Roman institutions. This is what the author claims. What this textbook really offers will be illuminated by quotations from his book, grouped according to the system adopted in the Roman law textbooks".

${ }_{17}$ This is done by J. Kodrębski (Borys Lapicki (1889-1974), [in:] Profesorowi Janowi Kodrębskiemu..., pp. 100-111; idem, Dzieje Katedry..., p. 41), who links the vicissitudes of life extremely closely with Łapicki's academic achievements. Kodrębski (Borys Łapicki (1889-1974), [in:] Profesorowi Janowi Kodrębskiemu..., p. 98) was most certainly correct stating that Łapicki's career had been created in very different circles and historical situations. Nevertheless, the same author often draws attention to what was persistent, unchanging, and continuous in Łapicki's accomplishments. T. Banach (Prawo rzymskie i etyka..., p. 97) states that 1948, the year when Prawo rzymskie was published, was an important turning point in periodisation of Łapicki's career. It behoves to agree with this only for the reason that vulgarised Marxism enters Łapicki's books in the later period. On the other hand, Łapicki's vision of Roman law is nevertheless unchanged - for at least the first one hundred pages of this textbook was on the problem of the Roman law ethics - and he did not abandon it after 1948. Other (less important divisions, in my opinion), see M. Zabłocka, Borys Łapicki..., pp. 162-163; T.A.J. Banyś, Ł.J. Korporowicz, op. cit., p. 133; J. Ożarowska-Sobieraj, M. Bromboszcz, op. cit., p. 74, etc.

${ }^{18}$ J. Kodrębski (Borys Łapicki (1889-1974), [in:] Profesorowi Janowi Kodrębskiemu ..., p. 106) concluded: "Admittedly, ethical law which was His ideal is a clearly undeveloped notion, but it is 
Assuming the accuracy of this observation, it can be said that the Legal Views were not an absolutely irrational, sudden and surprising reversal in the author's achievements, and thus the book cannot be treated only as a powerful break in Lapicki's work. ${ }^{19}$

In the résumé of the Romanist from Lodz one should notice one more matter which is important for the rationalisation of the nature of his research and intellectual attitude. For it seems that in relation to the evaluation of these achievements, the category of novelty and originality should be used with great caution. ${ }^{20}$ It appears that the above-mentioned basic trends/directions, but also a means to their research, should rather be observed through the eye of an analyst who, in a relatively large collection, finds elements on a complex and other than the author's provenance. I believe that only then one can notice a feature characteristic for Łapicki's achievements - here I have in mind a kind of eclecticism of his thought. However, this dominant should be perceived within a specific framework which should indicate the roles of certain inspirations rather than the automatic emulation.

Apart from the nuancing of strength and intensity of this "syncretism", it should be stated with certainty that Łapicki was not the first one to notice the ethical values of the Roman law (I repeat, they were almost iconic and constitutive in the perception of his achievements!). It seems obvious that in this respect he referred to the then innovative views of Leon Petrażycki on the role and nature of law and its relationship with morality and ethics. ${ }^{21}$ However, these inspirations were not

sufficiently clear in order to be included in a group of legal-natural doctrines which - for obvious reasons - went through their Renaissance after World War II".

19 This breach is rather unjustifiably described by M. Bromboszcz (op. cit., p. 75, 80). Even if he approached the Legal Views from the perspective of the subject and method, perhaps it would be worth to pay attention to how many and in what form the comments on slavery had been mentioned in the earlier (i.e. Władza ojcowska, Prawo rzymskie) and later works by Lapicki. The method has also not changed so much that one has to treat it in a category of a complete novelty. More about this below. It is obvious that numerous references to the Marxist classics and concepts typical for the Marxist methodology appear in the works issued after the publication of the Legal Views. The book from 1955 was not unique in this context, see, e.g., the Lapicki's article Ideologiczna obrona i krytyka własności jednostkowej w starożytnym Rzymie („Przegląd Socjologiczny” 1958, no. 12, pp. 205-228).

${ }^{20}$ Originality (pioneering) of the Legal Views fits almost exclusively in the "customary comments" made even in the most critical reviews of the work. Cf. M. Staszków, op. cit., pp. 321-322. It seems that similar in its nature was the opinion by J. Klima (op. cit., p. 444) on how Lapicki's plans were very ambitious and unprecedented in scholarship. For J. Kodrębski (Dzieje Katedry..., p. 41), the "novelty" was equal to the boldness of Łapicki's theses. Kodrębski exaggerated in referring to Łapicki as a precursor of research in the field of mentalité.

${ }^{21}$ With the abundance of publications on these relationships, it is worth to recall the works by the "Great Romantic", Leon Petrażycki: O pobudkach postępowania i o istocie moralności i prawa (Warszawa 1904), and posthumously published Wstęp do nauki prawa i moralności. Podstawy psychologii emocjonalnej (Warszawa 1959) and Teoria prawa i państwa w związku z teoria moralności 
articulated strongly enough by Łapicki to have the name of Borys Łapicki as a student of the "Great Romantic" to appear in Petrażycki's rich literature who, after all, began his academic fascinations with interest in the Roman law. ${ }^{22}$

It seems - although this assessment is even more subtle than the one articulated (implied) above - that Lapicki managed to get inspired by the idea of solidarism which was so important in his vision of Rome via Petrażycki. This intriguing and attractive - and often even contradictory for many political mainstreams - doctrine became popularised in the $19^{\text {th }}$ century in France as an intellectual protest against social and economic rules of capitalism, and in nearly all of its mutations it was based on the unity of activities and thought of the members of society (ergo, on the cooperation of its individual classes), their equality based on brotherhood (eliminating competition), service of an individual towards a community reciprocating it, and economy based on ethics and justice. A lot of attention in this highly utopian, but nevertheless beautiful concept, was placed on human freedom (more importantly, it could not be limited by another man because freedom always remains an inalienable right). ${ }^{23}$

Although no one mentions expressis verbis any potential influences of solidarism on Łapicki, it can be presumed that the presence of these motives in the

(vol. 1-2. Warszawa 1959-1960). An essential interpretation of the first book in particular is provided by M. Kik (Leona Petrażyckiego filozofia prawa, „Czasopismo Filozoficzne” 2006, no. 1, pp. 52-60).

22 There is not even a word on Łapicki in the collective work: Leon Petrażycki i jego dzieto (eds. M. Zubik, K. Koźmiński, K. Szczucki, „Studia Iuridica” 2018, vol. 74). Similarly, see, e.g., J. Kowalski, Psychologiczna teoria prawa i państwa Leona Petrażyckiego, Warszawa 1963; H. Leszczyna, Petrażycki, Warszawa 1974; K. Motyka, Wpływ Leona Petrażyckiego na polska teorię i socjologię prawa, Lublin 1993; A. Habrat, Ideał człowieka i społeczeństwa w teorii Leona Petrażyckiego, Rzeszów 2006. Similarity between Petrażycki's views and Łapicki's assessments emerges particularly from some of the studies. See, e.g., J. Jaskiernia, Prawo zwyczajowe w pogladach Leona Petrażyckiego, [in:] Prawo i nauka w pogladach Leona Petrażyckiego, eds. D. Gil, Ł. Pikuła, Lublin 2013, pp. 17-33; Ł.J. Pikuła, Ideat społeczny i odrodzenie prawa naturalnego w świetle polemiki między Rudolfem Stammlerem a Leonem Petrażyckim, [in:] Prawo i nauka ..., pp. 69-77; J. Główka, Pobudki utylitarystyczne i krytyka pozytywizmu prawniczego w ujęciu autorytetu L. Petrażyckiego i G. Radbrucha, [in:] Prawo i nauka ..., pp. 153-179.

23 This doctrine "was winning over" a certain group of lawyers - particularly those who were convinced of close relations between law and morality - in the interwar period. See, e.g., P. Fiktus, Prawo $w$ doktrynie solidaryzmu na przyktadzie myśli prawnej Leopolda Caro, [in:] Pozytywizm prawniczy i szkoła prawa natury - tradycje sporu i jego współczesne implikacje, eds. P. Kaczmarek, Ł. Machaj, Wrocław 2010, pp. 81-86. Even though L. Caro proposed solidarism in the Catholic dimension, it would be in vain to assume that Łapicki's religious abstinence could have been a significant barrier in getting to know the rudiments of this idea. On Lapicki's "secularity", see J. Kodrębski, Borys Eapicki (1889-1974), [in:] Profesorowi Janowi Kodrębskiemu..., p. 10. It should be remembered that the works by the precursors of solidarism were fairly quickly translated into Polish: Ch. Gide, Miłosierdzie, sprawiedliwość i dobór naturalny, Warszawa 1900; idem, Znaczenie idei solidarności w programie ekonomicznym, Warszawa 1907; L. Duguit, Kierunki rozwoju prawa cywilnego od początku XIX wieku, Warszawa-Kraków 1938. 
author of the Legal Views was facilitated by an undeniable role of this inspiring idea in some of the shades of the Russian liberalism, ${ }^{24}$ in the opinions expressed by Petrażycki, ${ }^{25}$ and in the discussions carried on about this idea in the circles of lawyers in Poland towards the end of the 1930s and in the period almost immediately preceding the writing of the Legal Views. ${ }^{26}$ It seems that it is also worth taking into consideration a research profile specific to Łapicki - the Roman law in the dogmatic form gradually played more limited role (see above) in the works by this Romanist. His studies probably always turned out to be closer to sociology and history, and these in turn were closer, e.g., to practising the views by Émile Durkheim, one of the co-creators of solidarism. ${ }^{27}$

It is worth to consider in what way this intellectual background - sketched briefly and almost as an encyclopaedic summary - could on the one hand affect the Legal Views in particular, and on the other hand, could help to resolve the dispute about Łapicki's contingent Marxism or conformism. Regarding the latter issue, it is worth to start with the significant characteristics of at least two of the four reviews known to me which were published in the "real" time, i.e. they were a direct reaction of the then academic world to Lapicki's monograph I am interested in.

Their young authors, ancient history and Roman law adepts, ${ }^{28}$ in a spirit more principled towards Marxism than "the condition of the method" presented in the

${ }^{24}$ Cf. S. Górka, Wolność, równość, solidarność. Myśl społeczno-polityczna Maksyma Kowalewskiego, Kraków 2006.

${ }_{25}$ On the ideal of love, altruism, and Petrażycki's solidarism based on ethics see footnotes 20 and 21. In the context of the following observations, it is noteworthy that Petrażycki believed that the law giver ought to support a natural tendency to eradicate egoistic behaviours and to enhance solidaristic behaviours. Cf., e.g., R. Zyzik, Czy Leon Petrażycki byt prekursorem behawioralnej ekonomicznej analizy prawa?, „Forum Prawnicze” 2016, p. 22.

${ }^{26}$ H. Dembiński, Teorie Duguita i Kelsena, Wilno 1931; F. Zoll, Z zagadnień funkcjonalizmu własności na tle spuścizny po Leonie Duguit, „Przegląd Notarialny” 1947, no. 1, pp. 1-15; J. Kalinowski, Teoria reguły społecznej i reguly prawnej Leona Duguita. Problem podstaw mocy obowiazujacej prawa. Studium filozoficzno-prawne, Lublin 1949.

27 Z. Cywiński (Tradycja petrażycjańska w polskiej socjologii prawa albo o tym, co zyskaliśmy, nie odwotując się do Ehrlicha, „Studia Iuridica” 2018, vol. 74, p. 103) writes: “If the problem concerns traditions present in the sociology of law, then it should be emphasised that they are in themselves a significant differentiating criterion. We will notice with no trouble the solidaristic motives for which Émile Durkheim's achievements are responsible, in both the French sociology of law and in its functionalist courses. It will be equally easy to indicate numerous references - important for the sociology of law - to Max Weber's sociology of law. Émile Durkheim is considered as one of the creators of solidarism".

${ }^{28}$ On the then status of the authors of the reviews, see T. Wituch, B. Stolarczyk, Studenci Instytutu Historycznego Uniwersytetu Warszawskiego 1945-2000, Kraków 2010, p. 138; S. Brzeziński, K. Fudalej, Pracownicy naukowo-dydaktyczni Instytutu Historycznego Uniwersytetu Warszawskiego 1930-2010. Stownik biograficzny, Warszawa 2012, p. 41; H. Kowalski, D. Słapek, Prof. dr hab. Tadeusz Łoposzko (1929-1994). Uczony, Nauczyciel, Człowiek, Lublin 2019 (manuscript), p. 16; E. Szymoszek, Michat Staszków jako romanista (1929-1992), „Z Dziejów Prawa” 2005, part 6, 
Legal Views, accused the author of the work on a class consciousness of slaves and proletarians of a clear apostasy from the thoughts of classicists on a new way of perceiving and researching the history of men. Although the problem of departing from the then orthodoxy occupies only a part of these reviews, the allegations of a lack of understanding and an authentic amateurishness in using historical materialism by Łapicki appear at the beginning, as preliminary, but then again probably fundamental, preceding the allegations of substantive nature: historical (review by Geremek, Łoposzko) and romanist (review by Staszkowa).

One of the "ideological" allegations present in both reviews was Łapicki's selectivity in the treatment and usage of the thoughts of the Marxism and Leninism classics. The author was even accused of superficial nature of the practised methodology: "In spite of numerous declarations from which it appears that the author is in favour of historical materialism, in the course of specific discussions Łapicki relies on the idealistic assumption that people's behaviour is at final instance determined by the ideology". ${ }^{29}$ Accusations appearing in the conclusions of one of the reviews sounded even sharper:

The subtitle affixed to the work, abundant quotations - most often superfluous - from the Marxist classics could give some readers the impression that the book is an attempt to make a Marxist analysis of the discussed problem. In fact, the work by Lapicki is non-Marxist, methodologically false, Łapicki's initial premises [...] are definitely idealistic in nature. The author frequently resorts to modernization while presenting antiquity. The "Marxist screen" of this non-Marxist book and the dishonest evidence apparatus creates danger that Łapicki's false views could be accepted at face value in the circles of non-specialists or could be seen as a low erudite level of research on Marxism amongst the bourgeois critics $[\ldots] .{ }^{30}$

pp. 9-21. The position of authors in usually hierarchical world of the academia can be a bit surprising if one was to juxtapose it with the harsh assessments of Łapicki's book. However, it should be remembered that reviewing works by the postgraduate students and young academics was the norm at University of Warsaw (cf. P. Guglielmonti, G.-M. Varanini, Wywiad z Karolem Modzelewskim, „Przegląd Historyczny” 2011, no. 1, p. 52). Additionally, disputes over Marxism in the academia engendered at that time mutual polemics and mutual admonishing by the followers of his method. See T. Siewierski, Inspiracje marksistowskie w twórczości Mariana Małowista, [in:] Zimowa szkoła historii najnowszej 2012, eds. Ł. Kamiński, G. Wołk, Warszawa 2012, p. 123; B. Czech-Jezierska, Ius publicum i ius privatum w pogladach tzw. romanistyki marksistowskiej (przykład Czechosłowacji), „Studia Prawno-Ekonomiczne” 2018, no. 108, p. 52.

29 B. Geremek, T. Łoposzko, op. cit., p. 394.

${ }^{30}$ Ibidem, p. 400. A similar approach is expressed slightly different by M. Staszków (op. cit., p. 321): "Lapicki undertook a self-critical assessment of his own achievements. Perhaps it would be difficult to regard short comments presented on p. 10 as self-criticism for they are too vague. The author's self-criticism is, first and foremost, the work under discussion. It is intended to 'straighten the line' of his previous research". The same author even wrote that Łapicki's monograph with its imperfect methodology - as the first one leading the way of Marxism in the Romanist studies - could cause more harm than good to this theoretical approach. For this reason, according to Staszków, it is absolutely necessary "to show all the dangers resulting from an erroneous understanding of the 
In a review of a reliable Czech historian of antiquity, Josef Češka, the Marxist principality does not play such an important role. Češka mentions Marxism only as a method used by Łapicki (e.g., "The development of the productive forces of the Roman agriculture was, according to Lapicki, a reason for the Roman imperialism"). However, the Czech historian writes: "New subjects require new methods for research work, but as we will show, the work by Łapicki is not always accurate and consistent, and his output is not as beneficial as an experienced scholar would have expected". Therefore, Łapicki did not use all the possible opportunities embedded in the new method apart from the fact that: "Already from the book that I have mentioned it is clear that all the conclusions made by Łapicki are not new. Many of them had already been expressed by the classics of Marxism and Leninism which were discovered thanks to the assumptions of the Soviet historians". Thus, Łapicki's conclusions are derivative and eclectic, and many of them had been already noticed by the classics of Marxism and Leninism. ${ }^{31}$ It seems that after all these remarks disparaging Łapicki as a Marxist (or rather a home-grown Marxologist! ${ }^{32}$ ) it is worth to get some distance from not always clearly articulated conviction that Łapicki "had believed" and took to this new reality - also the scholarly one - like a fish to water. ${ }^{33}$ After all, his later books also treat Marxism rather ostensibly - the author recalls its basic determinants in a very general, almost illustrative way (the class struggle is somewhat lost in Łapicki's "world of ideas", but the foundation and superstructure always remain to be $u \mathrm{de}^{34}$ ). Finally, it is worth to consider - if

guidelines of the Marxist methodology, starting with minor misunderstandings and ending with pseudo-Marxist outlines of a plain vulgarisation" (ibidem, p. 322). Łapicki's selectivity towards Marxism is expressed by the reviewer through an objection against "citatology".

31 J. Češka, op. cit., pp. 193-196.

32 On terminological subtleties and pejorative notion of "Marxism", see T. Siewierski, op. cit., p. 123.

${ }^{33}$ Cf. J. Kodrębski, Borys Lapicki (1889-1974), [in:] Profesorowi Janowi Kodrębskiemu..., pp. 110-111. The author concluded a little excessively: "The work in question is significant for the biographer of B. Łapicki because in contrast to the above-mentioned liberal declarations of the Scholar, it has a clear support in favour of Marxism”. Later on Kodrębski slightly softens his unequivocal opinion, stating that to recall the classics was "undoubtedly a commonly used protective camouflage, $[\ldots]$ the work was written in the apogee of Polish Stalinism and its author could have had reasons to worry - at the same time an attempt to accept the Marxist method was - as I believe - honest. This probably resulted partly from the widespread reign of Marxism in the humanities - not only in the Eastern Europe - which very effectively influenced researchers, and partly from the possibility to interpret Marxism in a way that was close to the academic and research needs of the Scholar, to who the formal and dogmatic method was always foreign and who tried to grasp in his studies the social reality rather than the normative condition". It would be probably worth to analyse this rather enigmatic statement that the inclination towards Marxism also resulted "from the possibility to interpret Marxism in a way that was close to the academic and research needs of the Scholar". See below.

${ }^{34}$ This was the case in O spadkobiercach ideologii rzymskiej. Okres chrystianizacji cesarstwa rzymskiego (Łódź 1962, pp. 89-105). 
Lapicki was to become a Marxist after all - the uniqueness of his path towards dogmatic historical materialism. It seems that it would be difficult to compare it with exemplary biographies of the declared Marxists whose paths to intellectual development had so far been meticulously researched by historiography historians. ${ }^{35}$

It appears that the Legal Views accumulate characteristics which are immanent for Lapicki's scholarly career. It is easy to find in them the Roman law ethics, the above-mentioned solidarism and the attempt of a conscious Marxism à la Lapicki. The best illustration of this melting pot of judgements and visions, and theoretical approaches is, i.a., the problem of the slave-proletarian alliance (including peregrines). The very title of Łapicki's monograph suggests a similarity of their status and existence of a certain community of interests of these two oppressed groups of the Roman society. In the vision of the Romanist from Lodz they were linked, first and foremost, by poverty and a position of an oppressed group - categories inherent in connecting/integrating people in accordance with the ideas of solidarism and not principally - as per Marxism - dividing them into antagonistic social classes which were distinguished only on the basis of a different attitude towards the means of production. Polish reviewers of Łapicki's work immediately noticed not only this ideological defect (after all proletarii were free people which distinguished them, not only in a context of the class, from slaves who were deprived of freedom) in the building of an almost elementary social stratification of the republican Rome in particular. ${ }^{36}$

It is most certainly worth to somehow substantiate this opinion on the solidaristic origins of a bizarre (from a historical perspective) alliance, a commonality of interests and opinions, and finally of slaves and proletarians. Therefore, it should be necessarily emphasised at first that drawing from the idea of solidarism and blurring the differences between the slaves and proletarians can, in fact, have only one alternative, ${ }^{37}$ which is even hard to imagine and accept - the ignorance of the author, professor of law, who was close in his studies to the problems of almost exclusively historical matter, in terms of fundamental social diversifications of

${ }^{35}$ It is impossible to compare (and this in not only due to generational differences) Lapicki's biography with K. Modzelewski, B. Geremek, W. Kula or M. Małowist. See, e.g., P. Guglielmonti, G.-M. Varanini, op. cit., pp. 45-106; T. Siewierski, op. cit., pp. 123-129.

${ }^{36}$ B. Geremek and T. Łoposzko (op. cit., pp. 398-399) proved that according to Lapicki the proletarii were also the poor representatives of the plebs, small-scale and landless farmers, poor residents of the cities and, finally, colonies. For the same reasons it was difficult for Łapicki to notice an internal diversification amongst slaves. Even J. Kodrębski (Borys Lapicki (1889-1974), [in:] Profesorowi Janowi Kodrębskiemu..., p. 110) wrote: "Lapicki's final thesis on the ideological closeness between slaves and proletarians still rises significant doubts".

37 This reservation has to be made because Łapicki used to approach historical social structures with a certain freedom (or rather - creative inventiveness). An example is. the "enlightened class" he created as a foundation for the author's discussion in Etyczna kultura starożytnego Rzymu a wczesne chrześcijaństwo from 1958! Cf. J. Ożarowska-Sobieraj, M. Bromboszcz, op. cit., pp. 76-77. 
ancient Rome! It can be assumed that while settling this dispute (whether it is a simple mistake, one-time-only omission, which theoretically can be made even in the book title?), it is also worth to recall the "Marxising" article by Lapicki in "Przegląd Socjologiczny" from 1958 which is slightly marginalised in the Romanist's career. The work was issued after the Legal Views had been published and after the above-mentioned reviews had been released, the blades of criticism of which had been directed against historicity of the "alliance" between slaves and proletarii. It can be assumed that practically everyone, particularly a heavily criticised author, usually tries as soon as possible to repair the mistakes and defects indicated in the reviews, especially since a few reviewers agreed on the same issue at the same time.$^{38}$ However, Łapicki did not do this because the problem did not concern an ordinary correction of a single factual error, but a change of lasting convictions, a certain vision of the Republican Rome (the period of time strongly idealized in Łapicki's works!) shaped due to the influence of the solidarism's idea. ${ }^{39}$ One can imagine that this unarticulated, unnamed, but almost mantrically repeated by the reviewers, who were principled towards the Marxist methodology, accusation of "idealistic approach" is caused precisely by the idea of solidarism practiced by Lapicki. ${ }^{40}$ It is believed that other manifestations of solidarism are still present in the Legal Views: in the conviction pushed forward by Łapicki on a gradual attenuation of law towards slaves in the period of the Principate, in the usage of modern term of the $19^{\text {th }}$ and $20^{\text {th }}$ centuries "nation" which is inadequate to the Roman reality, in treating Catiline as a political front-runner and a socially thoughtful leader who was sensitive misfortune of slaves and proletarians. ${ }^{41}$

38 As a proof, M. Staszków (op. cit., p. 321) wrote that the pre-war works by Łapicki "while presenting the history of the Roman law, they gave solidaristic interpretation which was no longer setting aside the class struggles, but simply denied its existence".

39 Łapicki, in the article Ideologiczna obrona i krytyka własności jednostkowej w starożytnym Rzymie, refers to the motives expressed in the Legal Views, where he writes that slaves questioned the masters' law of ownership (p. 72) and he practises a solidaristic notion of "the oppressed classes" (importantly, in the plural form!). Cf. J. Češka, op. cit., p. 194.

40 Łapicki's idealism is sometimes perceived by the reviewers as the author's inclination to favour utopias. B. Geremek and T. Łoposzko (op. cit., p. 394) write that one of Łapicki's assumptions "is so highly idealistic that it can be proved only by one of the transpositions of Platonic ideals on social activities of people and classes" (cf. ibidem, p. 398). M. Staszków (op. cit., p. 333) writes directly about solidarism of the Romanist from Łódź: "Having stated that there were opposing opinions of slaves and their masters, Prof. Łapicki emphasises at the same time [distinction-D.S.] that there was harmony and solidarity in Rome in the relations between slaves and proletarians". Staszków, however, notes that the pre-war works by Łapicki "were based on idealistic research assumptions" (ibidem, p. 321). Simultaneously, the reviewer expressed hope that the Legal Views were different in this respect...

${ }^{41}$ See B. Geremek, T. Łoposzko, op. cit., p. 395, 398, 400. T. Banach (Prawo rzymskie i etyka..., pp. 98-99) suggests that the modern concept of "nation" standing above state could have been borrowed from the national thought. Łapicki's eclecticism in this respect is confirmed by J. Kodrębski 
Another problem illustrating Łapicki's certain scholarly eclecticism (as well as close to this researcher's belief in the attachment to the idea of solidarism and ethics of law) is associated with a key concept for the book about slaves of ius naturale and the role of natural law in explaining the essence or rather the origins of the institution of slavery. Staszków-Romanist was quick to grasp the sense of Łapicki's perception of the nature of slavery: slaves were captivi - captured foreigners (hostes) and therefore these slaves regarded themselves as both free and foreign. According to national law, they never lost their freedom since in this case the slaves' national law refused legal authority to prisoners of war. In his review, Staszków quite efficiently proved the weakness of the above-mentioned thesis by Łapicki, and its rebuttal was regarded by him as a sufficient reason to refrain from further criticism of the work. ${ }^{42}$

A young, at that time, Romanist from Wrocław did not reach, however, to the genesis of Łapicki's views, and through the arguments of Romanist nature he demonstrated "an inconclusive approach" to the problem of foreign enemies. ${ }^{43}$ It seems that the core of Lapicki's convictions - erroneous to Staszków - was once again present in somewhat mechanical, ahistorical, but absolutely "morally beautiful" use by the author of the Legal Views of the idea of solidarism and a natural human right to freedom. ${ }^{44}$ Cited in the previous work by Lapicki Leon Duguit, ${ }^{45}$ a fervent supporter of the ethics of law and one of the co-creators of solidarism, wrote that a person who has a free will is a free man and, simultaneously, a holder of natural laws which by their nature are unalienable and are not time-barred. ${ }^{46}$

(Borys Lapicki (1889-1974), [in:] Profesorowi Janowi Kodrębskiemu..., p. 108), who reminds that the original notion of the Roman people had already been used by Lapicki in his Prawo rzymskie from 1948. It is worth to add that this synthesis also manifests a thoroughly solidaristic idea of the influence of morality over mitigation of slavery...

${ }_{42}$ M. Staszków, op. cit., pp. 327-330. Cf. B. Łapicki, Poglady prawne ..., pp. 63-67. M. Bromboszcz (op. cit., p. 82) correctly stated the importance of this issue, but he did not carry out its legal exegesis (defining its academic significance).

${ }_{43}$ As M. Staszków (op. cit., p. 331) writes: "In view of the claim that the author's approach towards the problem of hostis, role of the law of war and the native law of a slave is not accurate, the vast majority of detailed assertions and findings remains without proof".

${ }_{44}$ Already in 1948 R. Taubenschlag (op. cit., pp. 485-486) reproached Lapicki for his attachment to this thesis: "Regarding slaves, the author claims (p. 85) that the primary position of a slave is similar to the position of a plebeian and that he is (p. 87, 91) a foreigner, whom (p. 91) the civil law refuses legal protection to a foreigner (!); that he is (p. 238) 'a man', homo, but also the source of destruction and misfortune which war had brought on Rome, that (p. 86) he gradually ceases to be a part of his master's wealth, but increasingly more often appears as a person (p. 87) 'having legal rights', and effectively a certain human dignity which deserves respect (cf. p. 91)".

${ }^{45}$ Duguit's influence on the content of Łapicki's monograph, Jednostka i państwo, is discussed by L. Górnicki (op. cit., pp. 234-235).

${ }^{46}$ L. Duguit, op. cit., pp. 15-20. 
If the above-mentioned suggestions regarding the original preserved sources and Łapicki's intellectual inspirations - which intrigued the young scholar probably already in the times before and during the interwar period - do not prove to be convincing, it is worth to use one more argument, i.e. evidence for an astonishing permanence and a great attachment to them by the author of the Legal Views. One should begin with a statement that this gentleman-Romanist ${ }^{47}$ consequently perambulated once chosen paths, considered as him. It appears that for this reason, Łapicki seemed to be unresponsive to usually negative reviews of his scholarly works; thus, he did not ignore them, he understood their sense but he felt/comprehended - in accordance with his own convictions - their irrelevance. ${ }^{48}$ The notion (and, first and foremost, validity) of aequitas which was cherished by him $^{49}$ made him persist with the vision of the Roman laws that he had long created. He usually responded to criticism with a deep and firm belief in the correctness of his view. ${ }^{50}$

Perhaps this steadfast attitude can convince to the fact that the suggestions on Łapicki's conformism and opportunism are not entirely justified in relation to the political realities of the early Polish People's Republic. ${ }^{51}$ The thesis on a certain opportunism and deliberate - or even to some extent "clever" - adaptation to the political reality, and the same requirements towards studies, seem to be put forward by Mateusz Bromboszcz. According to his opinion, it was the pressure from the

47 The son, Andrzej, recalled: "The Roman law was to my father not only a set of rules which were meant to be followed, but a reference point in life. The Roman law was a kind of faith for him" (K. Bielas, J. Szczerba, op. cit.).

${ }^{48}$ It seems that he felt the criticism of his opinions as the lack of understanding for his ideals, threated by him as a kind of message - this feeling strongly limits the willingness to constant polemics and any reaction. Son Andrzej wrote that his father "remembered harmful opinions about him for a long time, they stuck inside him like a thorn" (ibidem).

49 T. Banach, Prawo rzymskie w pogladach wybranych przedstawicieli młodego pokolenia Narodowej Demokracji w okresie międzywojennym, [in:] Quid leges sine moribus? Studia nad prawem rzymskim dedykowane Profesorowi Markowi Kuryłowiczowi w 65. rocznicę urodzin oraz 40-lecie pracy naukowej, ed. K. Amielańczyk, Lublin 2009, p. 194; idem, Prawo rzymskie i etyka ..., passim.

${ }_{50}$ See, e.g., B. Łapicki, Odpowiedź na recenzję R. Taubenschlaga, „Myśl Współczesna” 1949, no. 10, pp. 113-125 (here, full of faith in the idea of moral values in the education of lawyers, a polemic with R. Taubenschlag). On usually critical reviews of Łapicki’s works, see J. Kodrębski, Borys Łapicki (1889-1974), [in:] Profesorowi Janowi Kodrębskiemu ..., p. 99, 109, 112; B. Czech-Jezierska, Okres dwudziestolecia międzywojennego a rozwój nauki prawa rzymskiego w Polsce, „Zeszyty Prawnicze UKSW" 2011, vol. 11(4), p. 17.

${ }^{51}$ It is worth to note that the Legal Views were published practically at the threshold of de-Stalinisation of Polish academia. See, e.g., M. Tyrchan, Nauki historycznoprawne w latach 60 XX wieku, „Krakowskie Studia z Historii Państwa i Prawa” 2012, no. 5, pp. 357-359. An experienced player should at least in theory anticipate political changes of courses, trends, and expectations, alleviating the Marxist dogmatism of his book... This type of thinking is put to an end by a comment by J. Kodrębski (Borys Lapicki (1889-1974), [in:] Profesorowi Janowi Kodrębskiemu ..., p. 110), that the book had been written already in 1951 (strangely, however, Łapicki used in the book materials which were published after 1951 [sic!]) when it was difficult to foresee the changes of 1956. 
politicised academic bodies (Conference of Polish Historians of Methodology from the beginning of the 1950s) of the dogmatic times of communism that decided on ideological and methodological dimension of the Legal Views. This nature of the book was, however, almost exclusively a conscious camouflage (a result of using forced "technical procedures"). ${ }^{52}$ However, Bromboszcz does not explain what Łapicki was supposed to hide. Having trust in Kodrębski's theory, it can be assumed that the camouflage protected his steadfast attitude of a self-declared liberal. Regardless of subtle differences between the above-mentioned authors, they would probably have been inclined to recognise that the Legal Views were a classic "sign of the times". Nevertheless, this generalisation does not explain much - it also marginalises the opinion on the fact that Lapicki did, in fact, believe in the new order or contested it in his own way. ${ }^{53}$

It also seems that as part of the recapitulation (to return to the topic of "did he believe?"), it is not enough to classify Łapicki to one of the categories typical for attitudes of Polish historians from the end of the 1940s and the beginning of the 1950s, sublimated from many academic biographies of that epoch by Tadeusz Rut-

${ }^{52}$ M. Bromboszcz (op. cit., p. 80) concludes: "In comparison with theses in Łapicki's monograph, the circumstances described here allow to provide an affirmative answer to the question on the relationship between this work and the then social and political situation. At the same time, the efforts made by the author can be assessed only as technical measures which were used by the scholar for the sake of the then Stalinist regime - it can be also concluded that these efforts were not a proof of change in the entire direction of the professor's research, still less a proof of change in his views". The same author (ibidem, p. 77) also introduces a motif of Łapicki as an altruistic fighter for the condition of discipline which was inimically treated by communists. The Legal Views were supposed to be a tool for fighting for the existence of the Roman law. According to J. Kodrębski (Borys Lapicki (1889-1974), [in:] Profesorowi Janowi Kodrębskiemu..., pp. 102-104), Łapicki’s book, Jednostka i państwo w starożytnym Rzymie (Warszawa 1939), which was idealistic and critical of the $20^{\text {th }}$ century totalitarianisms, could have been a reason for his more closely unspecified concerns. On the other hand, the Legal Views were supposed to be an absolution for this pre-war guilt (which was proven in 1949 by taking away from Łapicki his lectures - liberal in their content - in the theory of law). However, could it really be that way since the gravity of the problem was not that great? What the communists wanted the most was for the Marxism dogma to be fully present in the first instance in the most recent history and history of law, but most certainly also in the periods closer to modern times. See, e.g., P. Gugliemotti, G.-M. Varanini, op. cit., p. 46.

53 J. Kodrębski, Borys Lapicki (1889-1974), [in:] Profesorowi Janowi Kodrębskiemu..., pp. 9394. Similarly: T. Banach, Prawo rzymskie i etyka..., p. 97. Kodrębski, as a source which is potentially the most suitable for recognising Lapicki's attitudes, is nevertheless not unambiguous in his opinions - his views include a motif of danger and absolution of faults, and reconciliation with the system. According to M. Jońca (op. cit., especially p. 69), traumatic war experiences and events taking place right after the war underlay the origins of Łapicki's ideological metamorphosis. They intensified the contesting of the Second Republic of Poland and the London Government, and this restrain resulted in attention towards the new reality. See also footnote 12. 
kowski. ${ }^{54}$ This can be done most easily by indicating a "middle" group. However, this decision requires a commentary because after all Łapicki was not indifferent towards Marxism, and many observations made above suggest that the Legal Views did not constitute a significant breach in his vision of the Roman law. Many doubts regarding the thesis on Łapicki's opportunism can also be indicated. The most likely account by Łapicki as a scholar (inclined to eclecticism of a liberal, but who was also attached to the notion of solidarism) on Marxism was coming down to the willingness to subjugate it. It was meant to depend on forming an odd synthesis of class struggles with social solidarism. Mixing water with fire could not be successful, ${ }^{55}$ but - in Lapicki's moral assessment - it was a significant fact that the author was able to control his own (the prominence of this word is immense!) Marxism. If this came down to the fact that with his entire and unchanged conviction, while treading the scholarly paths that were considered his own (ethics of law, solidarism, rejection of legal dogmatism in favour of sociological and historical studies), Łapicki tried to adapt to them the dogmatic Marxism then it was not Marxism that took control over Lapicki (as the discussed reviews suggest) but the other way around. It can be said somewhat literary that in a conscious and somehow controlled (even if selective) way, Łapicki included Marxism in his vision of the Roman law and the Roman ideology (and it should be added that he believed in Marxism in his own way). The outcome of this deliberate procedure was a strongly intriguing, idealistic and Marxist, vision of the world and Roman law. Luckily enough - to judge by the number of modern works on the ethical values of the Roman law - it is quite effectively inspiring in one of its parts. ${ }^{56}$

54 T. Rutkowski, Nauki historyczne w Polsce 1944-1970. Zagadnienia polityczne i organizacyjne, Warszawa 2007, passim. The author considered three major attitudes as the most accurate for this period: conservative "defensive" current, "intermediate" attitude, and Marxist current. The latter, what is quite significant, was developed after 1945 in the academic circles in Warsaw and Lodz. The author interests also extend to the studies on history and law. Slightly different classification is made by R. Sitek (Warszawska szkoła historii idei. Między historia a teraźniejszościa, Warszawa 2000, pp. 106-108).

${ }_{55}$ M. Staszków, op. cit., p. 333. As I reiterate, Łapicki "are the same time emphasised" the struggle of classes and solidarity between slaves and proletarians.

56 J. Kodrębski, Borys Łapicki (1889-1974), [in:] Profesorowi Janowi Kodrębskiemu ..., p. 106. Cf. M. Zabłocka, Romanistyka polska ..., pp. 105-107. 


\section{REFERENCES}

\section{Literature}

Ad laudem magistri nostri. Mistrzowie dzieła polskiej romanistyki, ed. E. Gajda, Torun 2018.

Banach T., Prawo rzymskie i etyka w pogladach Borysa Lapickiego, „Studia Iuridica Lublinensia” 2007, vol. 10.

Banach T., Prawo rzymskie w pogladach wybranych przedstawicieli młodego pokolenia Narodowej Demokracji w okresie międzywojennym, [in:] Quid leges sine moribus? Studia nad prawem rzymskim dedykowane Profesorowi Markowi Kuryłowiczowi w 65. rocznicę urodzin oraz 40-lecie pracy naukowej, ed. K. Amielańczyk, Lublin 2009.

Banyś T.A.J., Korporowicz Ł.J., Borys Łapicki, [in:] 70 lat Wydziału Prawa i Administracji Uniwersytetu Łódzkiego, eds. A. Liszewska, A. Pikulska-Radomska, Łódź 2015.

Borys Łapicki, „ŁTN. Sprawozdania z Czynności i Posiedzeń 1948” 1949, no 1.

Bromboszcz M., Romanista w czasach stalinizmu - Borys Lapicki o powstaniach oraz walce niewolników z panami, [in:] Wojna i pokój. Wybrane zagadnienia prawno-historyczne, eds. E. Kozerska, P. Sadowski, A. Szymański, Opole 2013.

Brzeziński S., Fudalej K., Pracownicy naukowo-dydaktyczni Instytutu Historycznego Uniwersytetu Warszawskiego 1930-2010. Stownik biograficzny, Warszawa 2012.

Cywiński Z., Tradycja petrażycjańska w polskiej socjologii prawa albo o tym, co zyskaliśmy, nie odwotujac się do Ehrlicha, „Studia Iuridica” 2018, vol. 74,

DOI: https://doi.org/10.5604/01.3001.0012.2293.

Czech-Jezierska B., Ius publicum i ius privatum w pogladach tzw. romanistyki marksistowskiej (przykład Czechosłowacji), „Studia Prawno-Ekonomiczne” 2018, no. 108.

Czech-Jezierska B., Okres dwudziestolecia międzywojennego a rozwój nauki prawa rzymskiego w Polsce, ,Zeszyty Prawnicze UKSW” 2011, vol. 11(4),

DOI: https://doi.org/10.21697/zp.2011.11.4.07.

Czech-Jezierska B., Polscy romaniści w czasie II wojny światowej, „Studia z Dziejów Państwa i Prawa” 2018, vol. 21.

Czech-Jezierska B., Prawo rzymskie w edukacji prawniczej w pierwszych latach Polski Ludowej (1944-1949), „Annales UMCS sectio G (Ius)” 2014, vol. 61(2),

DOI: https://doi.org/10.17951/g.2014.61.2.31.

Czech-Jezierska B., Wolność i godność w starożytnym Rzymie - dobra osobiste czy społeczne? Kilka uwag na tle poglądów Borysa Łapickiego, [in:] Naruszenie dobra osobistego i zadośćuczynienie, Olsztyn (in print).

Czech-Jezierska B., Dębiński A., Prawo rzymskie w Polsce w latach 1939-1945, „Zeszyty Prawnicze” 2017, vol. 17(3), DOI: https://doi.org/10.21697/zp.2017.17.3.01.

Češka J., Łapicki, Borys. Poglądy prawne niewolników i proletariuszy rzymskich, „Sborník prací Filozofické fakulty brněnské univerzity. E-Řada archeologicko-klasická” 1956, vol. 5(E1).

Dembiński H., Teorie Duguita i Kelsena, Wilno 1931.

Duguit L., Kierunki rozwoju prawa cywilnego od początku XIX wieku, Warszawa-Kraków 1938.

Dzikowski A., Nauczanie prawa rzymskiego na studiach prawniczych w Polsce w latach 1918-1989. Konflikt ideologiczny o znaczeniu praktycznym, „Kortowski Przegląd Prawniczy” 2017, no. 4.

Fertacz S., Przyczynek do powstania i działalności Kongresu Stowian Amerykańskich w latach drugiej wojny światowej, „Kwartalnik Historyczny” 1993, no. 2.

Fiktus P., Prawo w doktrynie solidaryzmu na przykładzie myśli prawnej Leopolda Caro, [in:] Pozytywizm prawniczy i szkoła prawa natury - tradycje sporu i jego współczesne implikacje, eds. P. Kaczmarek, Ł. Machaj, Wrocław 2010. 
Geremek B., Łoposzko T., rec. Borys Łapicki, Poglądy prawne niewolników i proletariuszy rzymskich. Studium historyczne na tle bazy gospodarczej i antagonizmów klasowych, Łódzkie Towarzystwo Naukowe, Łódź 1955, s. 241, „Przegląd Historyczny” 1956, vol. 47(2).

Gide Ch., Mitosierdzie, sprawiedliwość i dobór naturalny, Warszawa 1900.

Gide Ch., Znaczenie idei solidarności w programie ekonomicznym, Warszawa 1907.

Główka J., Pobudki utylitarystyczne i krytyka pozytywizmu prawniczego w ujęciu autorytetu L. Petrażyckiego i G. Radbrucha, [in:] Prawo i nauka w pogląach Leona Petrażyckiego, eds. D. Gil, Ł. Pikuła, Lublin 2013.

Górka S., Wolność, równość, solidarność. Myśl społeczno-polityczna Maksyma Kowalewskiego, Kraków 2006.

Górnicki L., Prawo Trzeciej Rzeszy w nauce i publicystyce prawniczej Polski międzywojennej (19331939), Bielsko-Biała 1993.

Gruszczyk M., Przyczynek do powstania i działalności Komitetu Stowiańskiego w Polsce w pierwszych latach po zakończeniu II wojny światowej, [in:] Władza a społeczeństwo, eds. A. Bryłka, T. Kałuski, M. Korbaś, Katowice 2016.

Guglielmonti P., Varanini G.-M., Wywiad z Karolem Modzelewskim, „Przegląd Historyczny” 2011, no. 1 .

Habrat A., Ideat czlowieka i społeczeństwa w teorii Leona Petrażyckiego, Rzeszów 2006.

Jakubowski I., Pikulska-Radomska A., Rau Z., Jan Kodrębski (1936-1997), [in:] 70 lat Wydziatu Prawa i Administracji Uniwersytetu Łódzkiego, eds. A. Liszewska, A. Pikulska-Radomska, Łódź 2015.

Jaskiernia J., Prawo zwyczajowe w pogladach Leona Petrażyckiego, [in:] Prawo i nauka w pogladach Leona Petrażyckiego, eds. D. Gil, Ł. Pikuła, Lublin 2013.

Jońca M., Działalność Borysa Łapickiego w latach okupacji hitlerowskiej, [in:] Ad laudem magistri nostri. Mistrzowie dzieła polskiej romanistyki, ed. E. Gajda, Torun 2018.

Kalinowski J., Teoria reguly społecznej i reguly prawnej Leona Duguita. Problem podstaw mocy obowiazujacej prawa. Studium filozoficzno-prawne, Lublin 1949.

Kik M., Leona Petrażyckiego filozofia prawa, „Czasopismo Filozoficzne” 2006, no. 1.

Kita J., Pytlas S., Profesorowie Uniwersytetu Łódzkiego w latach 1945-1994. Pro memoria, Łódź 1995.

Klima J., rev., „Rivista internazionale di diritto romano e antico” 1957, vol. 8.

Kodrębski J., Borys Łapicki, „ŁTN. Sprawozdania z Czynności i Posiedzeń 1924-1977” 1979.

Kodrębski J., Borys Łapicki (1889-1974), [in:] Profesorowi Janowi Kodrębskiemu in memoriam, ed. A. Pikulska-Robaszkiewicz, Łódź 2000.

Kodrębski J., Borys Łapicki (1889-1974), „Czasopismo Prawno-Historyczne” 1974, vol. 26(2).

Kodrębski J., Borys Łapicki (1889-1974), „Zeszyty Naukowe Uniwersytetu Łódzkiego. Nauki Humanistyczno-Społeczne" 1976, no. 26.

Kodrębski J., Dzieje Katedry Prawa Rzymskiego, „Acta Universitatis Lodziensis. Folia Iuridica” 1997, no. 64.

Kodrębski J., Wydział Prawa i Administracji UŁ w l. 1945-1995. Szkic do historii, „Acta Universitatis Lodziensis. Folia Iuridica" 1997, no. 64.

Kowalski H., Słapek D., Prof. dr hab. Tadeusz Łoposzko (1929-1994). Uczony, Nauczyciel, Człowiek, Lublin 2019 (manuscript).

Kowalski J., Psychologiczna teoria prawa i państwa Leona Petrażyckiego, Warszawa 1963.

Leon Petrażycki i jego dzieto, eds. M. Zubik, K. Koźmiński, K. Szczucki, „Studia Iuridica” 2018, vol. 74.

Leszczyna H., Petrażycki, Warszawa 1974.

Litewski W., s.v. Łapicki Borys, [in:] idem, Stownik encyklopedyczny prawa rzymskiego, Kraków 2008. Łapicki B., Etyczna kultura starożytnego Rzymu a wczesne chrześcijaństwo, Wrocław-Lódź 1958. 
Łapicki B., Ideologiczna obrona i krytyka własności jednostkowej w starożytnym Rzymie, „Przegląd Socjologiczny" 1958, no. 12.

Łapicki B., Jednostka i państwo w Rzymie starożytnym. Rozważania historyczne na tle przeobrażeń prawa i państwa i prawa w dobie obecnej, Warszawa 1939.

Łapicki B., O humanistycznym wychowaniu prawnika, „Państwo i Prawo” 1948, no. 5-6.

Łapicki B., O spadkobiercach ideologii rzymskiej. Okres chrystianizacji cesarstwa rzymskiego, Łódź 1962.

Łapicki B., Odpowiedź na recenzję R. Taubenschlaga, „Myśl Współczesna” 1949, no. 10.

Łapicki B., Poglądy prawne niewolników i proletariuszy rzymskich. Studium historyczne na tle bazy gospodarczej i antagonizmów klasowych, Łódź 1955.

Łapicki B., Teoria prawa wedtug wykładów na UŁ, Łódź 1947.

Łapicki B., Władza ojcowska w starożytnym Rzymie. Okres królewski i republikański, Warszawa 1935.

Motyka K., Wptyw Leona Petrażyckiego na polska teorię i socjologię prawa, Lublin 1993.

Ożarowska-Sobieraj J., Bromboszcz M., Ideologia warstwy oświeconej-inteligencji rzymskiej okresu pryncypatu w poglądach Borysa Łapickiego, [in:] Egalitaryzm i elitaryzm. Tradycja i przyszłość Europy, eds. E. Kozerska, P. Sadowski, A. Szymański, Opole 2012.

Petrażycki L., O pobudkach postępowania i o istocie moralności i prawa, Warszawa 1904.

Petrażycki L., Teoria prawa i państwa w związu z teoria moralności, vol. 1-2. Warszawa 1959-1960.

Petrażycki L., Wstęp do nauki prawa i moralności. Podstawy psychologii emocjonalnej, Warszawa 1959.

Pikulska-Radomska A., Sylwetki łódzkich uczonych. Prof. Jan Kodrębski, Łódź 2008.

Pikuła Ł.J., Ideat społeczny $i$ odrodzenie prawa naturalnego $w$ świetle polemiki między Rudolfem Stammlerem a Leonem Petrażyckim, [in:] Prawo i nauka w pogladach Leona Petrażyckiego, eds. D. Gil, Ł. Pikuła, Lublin 2013.

Prof. dr Borys Lapicki, „Prawo i Życie” 1974, no. 8.

Przeciszewska M., Dyskusje o rosyjskiej polityce liberalnej. Środowisko Partii Konstytucyjno-Demokratycznej, 1905-1914, Warszawa 2013 (doctoral dissertation written under the supervision of T. Kizwalter).

Report on the Amercian Slav Congress and Associated Organizations, June 26, 1949, Washington 1950.

Rutkowski T., Nauki historyczne w Polsce 1944-1970. Zagadnienia polityczne i organizacyjne, Warszawa 2007.

Siewierski T., Inspiracje marksistowskie w twórczości Mariana Małowista, [in:] Zimowa szkoła historii najnowszej 2012, eds. Ł. Kamiński, G. Wołk, Warszawa 2012.

Sitek R., Warszawska szkoła historii idei. Między historia a teraźniejszościa, Warszawa 2000.

Staszków M., W sprawie „Pogladów prawnych niewolników i proletariuszy rzymskich” (uwagi na tle pracy prof. Borysa Łapickiego), „Czasopismo Prawno-Historyczne” 1956, vol. 8(2).

Szymoszek E., Michat Staszków jako romanista (1929-1992), „Z Dziejów Prawa” 2005, part 6.

Taubenschlag R., ,,Prawo rzymskie”, Borys Łapicki, Warszawa 1948 [rec.], „Czasopismo Prawno-Historyczne" 1949, vol. 2.

Tokarczyk R., Antologia anegdoty akademickiej, Warszawa 2006.

Tyrchan M., Nauki historycznoprawne w latach 60 XX wieku, „Krakowskie Studia z Historii Państwa i Prawa" 2012, no. 5.

Wierzbowski B., Treść władzy ojcowskiej w rzymskim prawie poklasycznym - władza nad osobami dzieci, Torun 1977.

Wituch T., Stolarczyk B., Studenci Instytutu Historycznego Uniwersytetu Warszawskiego 1945-2000, Kraków 2010.

Zabłocka M., Badania romanistów polskich w latach 2011-2013, „Zeszyty Prawnicze UKSW” 2015, vol. 15(2), DOI: https://doi.org/10.21697/zp.2015.15.2.10. 
Zabłocka M., Borys Łapicki (1889-1974), [in:] Profesorowie Wydziału Prawa i Administracji Uniwersytetu Warszawskiego 1808-2008, ed. G. Bałtruszajtys, Warszawa 2008.

Zabłocka M., Gorsze lata polskiej romanistyki, „Zeszyty Prawnicze UKSW” 2017, vol. 17(4), DOI: https://doi.org/10.21697/zp.2017.17.4.07.

Zabłocka M., Romanistyka polska w pierwszym dziesięcioleciu XXI wieku, Warszawa 2013.

Zoll F., Z zagadnień funkcjonalizmu własności na tle spuścizny po Leonie Duguit, „Przegląd Notarialny" 1947 , no. 1.

Zysiak A., Punkty za pochodzenie. Powojenna modernizacja i uniwersytet $w$ robotniczym mieście, Kraków 2016.

Zyzik R., Czy Leon Petrażycki byt prekursorem behawioralnej ekonomicznej analizy prawa?, „Forum Prawnicze" 2016.

\section{Netography}

Bielas K., Szczerba J., Nie zabiliby panowie królika. Cz. 1. Rozmowa z Andrzejem Łapickim, „Gazeta Wyborcza”, 5.03.1999, http://niniwa22.cba.pl/lapicki_wywiad_1.htm [access: 10.12.2020].

\section{ABSTRAKT}

W historii polskiej romanistyki epoki PRL postać Borysa Łapickiego budzi spore zainteresowanie głównie z racji jego kontrowersyjnej monografii Poglądy prawne niewolników i proletariuszy rzymskich z 1955 r. Wydaje się, że nie do końca słusznie traktuje się ją jako wyłom w dorobku łódzkiego romanisty. Powodów jej wyjątkowości poszukuje się zwykle w skomplikowanej biografii autora, którą traktuje się jako swego rodzaju ,znak czasu”. Tymczasem recenzje pracy opublikowane tuż po jej ukazaniu się jednoznacznie wykazały, że dogmatyczny marksizm Łapicki poddał swego rodzaju adaptacji, próbując godzić go z od dawna akceptowanymi przez siebie ideami solidaryzmu i wiarą w wartości etyczne prawa rzymskiego. Wierność tym ideom sprawiła, że ten amalgamat trudnych do pogodzenia ze sobą konceptów (walka klas wobec opartej na wolności i braterstwie harmonii) okazał się niemożliwy do zaakceptowania. Wydaje się, że tej eklektycznej formuły nikt Łapickiemu nie narzucał - nie była przejawem konformizmu lub koniunkturalizmu autora. Mimo niezwykle ostrej krytyki nie odszedł od niej nawet w czasach, gdy materializm historyczny wyszedł z dogmatycznej fazy swego rozwoju. Niniejszy artykuł stanowi rodzaj case study - przyczynek do studiów nad szerszą kwestią tożsamości i postaw polskich romanistów w okresie stalinizmu.

Słowa kluczowe: Borys Łapicki; niewolnictwo rzymskie; marksizm; solidaryzm; prawo rzymskie; polska romanistyka epoki PRL 